\title{
Effect of Stryphnodendron adstringens (barbatimão) bark on animal models of nociception
}

\author{
Juliana Oliveira de Melo' ${ }^{1}$ Tânia Hiromi Endo', Luiz Eduardo Bersani-Amado', \\ Arthur Estivalet Svidzinski ${ }^{1}$, Silmara Baroni ${ }^{1}$, João Carlos Palazzo de Mello ${ }^{2}$ and \\ Ciomar Aparecida Bersani-Amado* ${ }^{\text {* }}$
}

\begin{abstract}
Department of Pharmacy and Pharmacology, 'Laboratory of Inflammation, '2Laboratory of Pharmacognosy,
\end{abstract} University of Maringá, Paraná

*Correspondence:

C. A. Bersani-Amado

Department of Pharmacy and

Pharmacology

Avenida Colombo, 5790

87020-900 - Maringá - PR, Brazil

E-mail: cabamado@uem.br
The antinociceptive activity of the crude extract and fractions of Stryphnodendron adstringens (Martius) Coville (barbatimão) was evaluated. Three experimental models of pain induction were used: abdominal writhing, formalin, and hot plate. The results demonstrated an antinociceptive effect of barbatimão in the experimental models of writhing induced by acetic acid and pain induced by formalin. However, the extracts did not significantly alter latency time on the hot plate in mice. These results suggest that barbatimão extract has a peripheral antinociceptive effect.
Uniterms

- Stryphnodendron adstringens

- Barbatimão,

- Antinociception

\section{INTRODUCTION}

Medicinal plants play an important role in folk medicine, and different plant species have been used in the treatment of many diseases. Detailed studies are necessary to prove their biological activity and provide necessary information about their therapeutic use.

Popularly known as barbatimão, Stryphnodendron adstringens (Mart.), Coville, Leguminosae, is a medicinal plant abundant in central Brazil and has long been used as a popular herbal medicine. Pharmacological studies with this plant have demonstrated that it possesses antiinflammatory properties (Bersani-Amado et al., 1996; Lima et al., 1998) and protects gastric mucous membranes (Audi et al., 1999). There also are reports that barbatimão extracts have cicatrizing (Lopes et al., 2005; Neves et al., 1992; Panizza et al., 1988), antioxidant (Lopes et al., 2005; Sanches et al., 2005), antiviral (Felipe et al., 2006), antiprotozoa (Holetz et al., 2005), and antimicrobial effects
(Audi et al., 1999; Ishida et al., 2006; Sanches et al., 2005).

The purpose of the present study was to evaluate the possible antinociceptive activity of the crude extract and fractions of barbatimão in several animals models of nociception.

\section{MATERIAL AND METHODS}

\section{Plant material and extract preparation}

The stem bark of Stryphnodendron adstringens (Martius) Coville, Leguminosae, was collected in São Jerônimo da Serra (longitude: $23^{\circ} 43^{\prime} 7.8^{\prime \prime}$ S; latitude: $50^{\circ}$ 45' 23.5" W; altitude: $926 \mathrm{~m}$ ) in the state of Paraná, Brazil, in October 1995. A voucher specimen was deposited at the Herbarium of the Biology Department under number HUM-3800. Air dried stem bark (1500 g) was extracted in Ultra-Turax ${ }^{\circledR}$ with Acetone: $\mathrm{H}_{2} \mathrm{O}(7: 3 ; \mathrm{v} / \mathrm{v})$. The organic 
solvent was eliminated by reduced pressure and lyophilised to yield a barbatimão crude extract (633 g). The lyophilized barbatimão crude extract (500 g) was resuspended in $\mathrm{H}_{2} \mathrm{O}$ and then fractionated with ethyl acetate to yield $\mathrm{H}_{2} \mathrm{O}\left(\mathrm{F}_{1} ; 386 \mathrm{~g}\right)$ and ethyl-acetate $\left(\mathrm{F}_{2} ; 98 \mathrm{~g}\right)$ fractions. Both $\mathrm{F}_{1}$ and $\mathrm{F}_{2}$ were concentrated under reduced pressure to eliminate the organic solvent, lyophilized, and stored at $-20{ }^{\circ} \mathrm{C}$. The barbatimão crude extract and fractions $F_{1}$ and $F_{2}$ were resuspended in distilled water at the desired concentrations before use.

\section{Animals}

Adult male Wistar rats weighing 200-220 g and male Swiss mice weighing 25-35 g were used. They were housed five per cage and maintained in a room with controlled temperature $\left(22 \pm 2^{\circ} \mathrm{C}\right)$ under a $12 \mathrm{~h}$ dark-light cycle with free access to standard chow and tap water throughout the experimental period. The protocol for these experiments was approved by the Animal Ethics Committee of University of Maringá under approval number 047/CEEA.

\section{Writhing test}

The response to intraperitoneal injection of $0.6 \%$ acetic acid (i.e., contraction of the abdominal muscles and elongation of the hind limbs) was induced by the method of Koster et al. (1959). Male Swiss mice (25-35 g, $n=8)$ were treated orally with the crude extract and fractions $\left(200,400\right.$, and $800 \mathrm{mg} / \mathrm{kg}$ body weight), indomethacin ${ }^{\circledR}$ (Sigma, $5 \mathrm{mg} / \mathrm{kg}$ body weight), the reference nonsteroidal anti-inflammatory drug, or saline (control group) $30 \mathrm{~min}$ before injection of $0.6 \%$ acetic acid $(0.1 \mathrm{ml} / 10 \mathrm{~g}$ body weight). The mice were placed in transparent glass cylinders, and the number of abdominal writhes produced in these animals was counted over a period of $20 \mathrm{~min}$. The antinociceptive activity was evaluated in terms of number of writhes.

\section{Formalin test}

The formalin test was performed according to the method described previously by Correa and Calixto (1993). The mice were treated orally with the crude extract and fractions $(800 \mathrm{mg} / \mathrm{kg}$ body weight $)$ or indomethacin $(5 \mathrm{mg} / \mathrm{kg}$ body weight) $30 \mathrm{~min}$ before intraplantar injection of $1 \%$ formalin $(0.5 \mathrm{ml})$ into the left hind paw of the animal. The animals were placed in a mirrored cylinder. The reaction to pain then was observed, and the time the animal spent licking or biting its paw was measured with a chronometer during the first phase $(0-5 \mathrm{~min}$, neurogenic pain) and during the second phase (15-35 min, tonic pain).

\section{Hot-plate test}

The latency time in the hot-plate test was measured by the method of Eddy and Leimback (1953). The animals were divided into groups of eight animals each. The temperature of the plate (Ugo Basile, Varese, Italy) was fixed at $55.0 \pm 0.5^{\circ} \mathrm{C}$. The latency time to exhibit a reaction (i.e., jumps, licking one of the hind limbs, or one of the forelimbs, tapping) was measured 30 and $60 \mathrm{~min}$ after administration of the crude extract and fractions $(800 \mathrm{mg} / \mathrm{kg}$ body weight, p.o.), meperidine ${ }^{\circledR}$ (Cristália, $50 \mathrm{mg} / \mathrm{kg}$ body weight, i.p.), the reference opioid analgesic drug, or saline (control group). Basal latencies were recorded before treatment. The cutoff time was $30 \mathrm{~s}$ to avoid tissue damage.

\section{Statistical analysis}

The results are presented as mean \pm standard error of the mean (S.E.M.). The data were subjected to analysis of variance (ANOVA) followed by Tukey's post hoc test. $P<0.05$ was considered as the significance level.

\section{RESULTS}

The barbatimão crude extract and both fractions, $\mathrm{F}_{1}$ (aqueous fraction) and $\mathrm{F}_{2}$ (ethyl-acetate fraction), dosedependently reduced acetic acid-induced writhing when administered orally (400 and $800 \mathrm{mg} / \mathrm{kg}$ body weight). Only the $\mathrm{F}_{1}$ fraction inhibited writhing at a dose of $200 \mathrm{mg} / \mathrm{kg}$ body weight. All of the extracts at the $800 \mathrm{mg} / \mathrm{kg}$ dose inhibited writhing similarly to indomethacin $(5 \mathrm{mg} / \mathrm{kg})$.

In the formalin test, the barbatimão crude extract and $\mathrm{F}_{1}$ fraction $(800 \mathrm{mg} / \mathrm{kg})$ caused marked inhibition only in the late phase. The $\mathrm{F}_{2}$ fraction was not effective in both phases of this model.

The barbatimão crude extract $(800 \mathrm{mg} / \mathrm{kg})$ and the $\mathrm{F}_{1}$ fraction $(800 \mathrm{mg} / \mathrm{kg})$ pretreatment increased response latency in the hot plate test. This effect, however, was very minimal compared to the effect of meperidine, the analgesic reference drug. Treatment with the $\mathrm{F}_{2}$ fraction did not alter the response time of the animals. Data are presented in Table I.

\section{DISCUSSION}

The results obtained in the present study demonstrated that the barbatimão crude extract and fractions exhibited antinociceptive activity in the models tested. This effect was more significant against chemically 
TABLE I - Analgesic activity of barbatimão extracts on nociception in the writhing, formalin, and hot plate tests.

\begin{tabular}{|c|c|c|c|c|c|c|}
\hline \multirow{2}{*}{$\begin{array}{l}\text { Treatment } \\
\text { (mg/kg body weight) }\end{array}$} & & \multirow{2}{*}{$\begin{array}{c}\text { Acetic acid } \\
\text { Number of writhings }\end{array}$} & \multicolumn{2}{|c|}{ Formalin test } & \multicolumn{2}{|c|}{ Hot plate test } \\
\hline & & & Early phase & Late phase & $30 \mathrm{~min}$ & $60 \mathrm{~min}$ \\
\hline Saline & & $68.4 \pm 3.3$ & $51.9 \pm 3.9$ & $239.2 \pm 20.0$ & $7.2 \pm 0.8$ & $8.3 \pm 0.8$ \\
\hline barbatimão & 200 & $54.0 \pm 7.0$ & - & - & - & - \\
\hline \multirow{2}{*}{ crude extracts } & 400 & $51.1 \pm 3.6^{*}$ & - & - & - & - \\
\hline & 800 & $24.9 \pm 7.2^{*}$ & $49.6 \pm 3.1$ & $130.5 \pm 7.7^{*}$ & $8.2 \pm 2.2$ & $12.6 \pm 1.3^{*}$ \\
\hline \multirow[t]{3}{*}{$F_{1}$} & 200 & $45.2 \pm 6.6^{*}$ & - & - & - & - \\
\hline & 400 & $30.2 \pm 3.8^{*}$ & - & - & - & - \\
\hline & 800 & $23.3 \pm 4.3^{*}$ & $46.7 \pm 7.0$ & $162.8 \pm 7.3^{*}$ & $10.8 \pm 1.6^{*}$ & $12.5 \pm 1.3^{*}$ \\
\hline \multirow[t]{3}{*}{$\mathbf{F}_{2}$} & 200 & $74.5 \pm 5.2$ & - & - & - & - \\
\hline & 400 & $52.1 \pm 6.2^{*}$ & - & - & - & - \\
\hline & 800 & $32.8 \pm 5.3^{*}$ & $53.1 \pm 7.5$ & $264.6 \pm 13.7$ & $9.6 \pm 0.9$ & $7.4 \pm 0.6$ \\
\hline Indomethacin & 5 & $23.1 \pm 5.3^{*}$ & $39.0 \pm 9.0$ & $44.8 \pm 11.8^{*}$ & - & - \\
\hline Meperidine & 50 & - & - & - & $28.6 \pm 0.9^{*}$ & $24.8 \pm 1.9^{*}$ \\
\hline
\end{tabular}

$\mathrm{F}_{1}=$ aqueous fraction; $\mathrm{F}_{2}=$ ethyl-acetate fraction. Values are the mean \pm S.E.M for 6-10 animals. Significant differences compared to controls (saline) were evaluated using ANOVA (Tukey-test) $* P<0.05$.

(acetic acid and formalin tests) than thermally (hot plate) induced nociception.

Acetic acid causes inflammatory pain by inducing capillary permeability (Amico-Roxas et al., 1984) and liberating endogenous substances that excite pain nerve endings (Raj, 1996). Traditional anti-inflammatory drugs (e.g., nonsteroidal anti-inflammatory drugs) inhibit COX in peripheral tissues, thus interfering with production of mediators that stimulate primary afferent nociceptors (Fields, 1987). The formalin test, characterized by two phases, is used to evaluate the mechanism by which an animal responds to moderate, continuous pain generated by the injured tissue (Abbott et al., 1995). The early phase (immediately after formalin injection) seems to be caused by $\mathrm{C}$-fiber activation induced by the peripheral stimulus. The late phase (starting approximately $20 \mathrm{~min}$ after injection) appears to depend on the combination of an inflammatory reaction, activation of $N$-methyl-D-aspartate (NMDA) and non-NMDA receptors, and the nitric oxide cascade (Davidson and Carlton, 1998) in the peripheral tissue and functional changes in the dorsal horn of the spinal cord (Abbott et al., 1995).

The extract showed remarkable activity in the writhing test induced by acetic acid and in the late phase of the formalin test, both related to a peripheral inflammatory pain (Ahmadiani et al., 1998; Collier et al., 1968). In contrast, the effects of the extract in the hot plate test, used to evaluate specific central antinociception (Parkhouse et al., 1979), were minimal. Although some doses showed a significant difference compared to the control group, the antinociceptive effect of meperidine (reference drug) was much more evident. In addition, the effect of crude extract and fractions in the early phase of the formalin test was not different from control. The nociception of this phase may be a direct result of stimulation of nociceptive neurons (Coderre, Melzack, 1992). The present study also demonstrated that the $F_{1}$ fraction showed greater efficacy than the crude extract and $\mathrm{F}_{2}$ fraction.

Phytochemical analysis indicates the presence of a proanthocyanidin polymer of molecular weight $2114 \mathrm{Da}$ in the aqueous fraction $\left(\mathrm{F}_{1}\right)$ (Ishida et al., 2006) and condensed tannins (flavan-3-ols and prodelphinidins and prorobinetinidins) in $\mathrm{F}_{2}$ (De Mello et al., 1996a, b, 1999).

From the data of this study we can conclude that the barbatimão extract has a peripheral antinociceptive effect. The mechanisms responsible for this effect are not completely understood, but it is possible that the substances responsible for the observed effect are concentrated in the $\mathrm{F}_{1}$ fraction.

\section{RESUMO}

\section{Efeito da casca de Stryphnodendron adstringens (barbatimão) em modelos de nocicepção animais}

A atividade antinociceptiva do extrato bruto e frações do Stryphnodendron adstringens (Mart.) Coville (barbatimão) foi avaliada. Foram usados três modelos experimentais 
para avaliação da dor: teste de contorção abdominal induzida pelo ácido acético, teste da formalina e teste da placa quente. Os resultados mostraram um efeito antinociceptivo evidente do barbatimão nos modelos experimentais de contorção induzida por ácido acético e dor induzida pela formalina. Por outro lado, o barbatimão não modificou significativamente o tempo de latência dos animais no teste da placa quente. Estes resultados sugerem que o extrato de barbatimão apresenta efeito antinociceptivo por mecanismos periféricos.

UNITERMOS: Stryphnodendron adstringens. Barbatimão. Antinocicepção.

\section{REFERENCES}

ABBOTT, F. V.; FRANKLIN, K. B.; WESTBROOK, R. F. The formalin test: scoring properties of the first and second phase of the pain response in rats. Pain, v. 60, p. 91-102, 1995.

AHMADIANI, A.; FEREIDONI. M.; SEMNANIAN, S.; KAMALINEJAD, M.; SAREMI, S. Antinociceptive and anti-inflammatory effects of Sambucus ebulus rhizome extract in rats. J. Ethnopharmacol., v. 61, p. 229-235, 1998.

AMICO-ROXAS, M.; CARUSO, A.; TROMBADORE, S.; SCIFO, R.; SCAPAGINI, U. Gangliosides antinociceptive effects in rodents. Arch. Int. Pharmacodyn. Ther., v. 272, p. 103-117, 1984.

AUDI. E. A.; TOLEDO, D. P.; PEREZ, P. G.; KIMURA, E.; PEREIRA W. K. V.; DE MELLO, J. C.; NAKAMURA, C.; ALVES-DO-PRADO, W., CUMAN, R. K.; BERSANI-AMADO, C. A. Gastric antiulcerogenic effects of Stryphnodendron adstringens in rats. Phytother. Res., v. 13, p. 264-266, 1999.

BERSANI-AMADO, C. A.; NAKAMURA, C. V.; NAKAMURA, T. U.; MARTINEZ, M.; MELLO, J. C. P. Avaliação das atividades antiinflamatória e antibacteriana do extrato bruto do Stryphnodendron adstringens (Barbatimão). In: SIMPÓSIO DE PLANTAS MEDICINAIS DO BRASIL. Resumos. Florianópolis, 1996. Florianópolis: [s.n.], [1996]. p.82.

CODERRE, T. J.; MELZACK, R. The contribution of excitatory amino acids to central sensitization and persistent nociception after formalin-induced tissue injury. J. Neurosci., v. 12, p. 3665-3670, 1992.
COLLIER, H. O.; DINNEN, L. C.; JOHNSON, C. A.; SCHNEIDER, C. The abdominal constriction response and its suppression by analgesic drugs in mice. $B r . J$. Pharmacol. Chemother., v. 32, p. 295-310, 1968.

CORREA, C. R.; CALIXTO, J. B. Evidence for participation of $\mathrm{B} 1$ and $\mathrm{B} 2$ kinin receptors in formalin-induced nociceptive response in the mouse. Br. J. Pharmacol., v. 110, p. 193-198, 1993.

DAVIDSON, E. M.; CARLTON, S. M. Intraplantar injection of dextrorphan, ketamine or mematine attenuates formalin-induced behaviors. Brain Res., v. 785, p. 136142, 1998.

DE MELLO, J. C. P.; PETEREIT, F.; NAHRSTEDT, A. Flavan-3-ols and prodelphinidins from Stryphnodendron adstringens. Phytochemistry, v. 41, p. 807-813, 1996a.

DE MELLO, J. C. P.; PETEREIT, F.; NAHRSTEDT, A. Prorobinetinidins from Stryphnodendron adstringens. Phytochemistry, v. 42, p. 857-862, $1996 \mathrm{~b}$.

DE MELLO, J. C. P.; PETEREIT, F.; NAHRSTEDT, A. A dimeric proanthocyanidin from Stryphnodendron adstringens. Phytochemistry, v. 51, p. 1105-1107, 1999.

EDDY, N. B.; LEIMBACK, D. Synthetic analgesics: II. Dithienylbutenyl- and dithienylbutylamines. $J$. Pharmacol. Exp. Ther., v. 107, p. 385-393, 1953.

FELIPE, A. M. M.; RINCÃO, V. P., BENATI, F. J.; LINHARES, R. E. C.; GALINA, K. J., DE TOLEDO, C. E.; LOPES, G. C.; MELLO, J. C. P.; NOZAWA, C. Antiviral effect of Guazuma ulmifolia and Stryphnodendron adstringens on poliovirus and bovine herpesvirus. Biol. Pharm. Bull., v. 29, n. 6, p. 1092-1095, 2006.

FIELDS, H.L. Analgesic drugs. In: FIELDS, H. L. (Ed.) Pain . New York: MacGraw-Hill, 1987, p. 272.

HOLETZ, F. B.; UEDA-NAKAMURA, T.; DIAS FILHO, B. P.; MELLO, J. C. P.; MORGADO-DÍAZ, J. A.; TOLEDO, C. E. M.; NAKAMURA, C. V. Biological effects of extracts obtained from Stryphnodendron adstringens on Herpetomonas samuelpessoai. Mem. Inst. Oswaldo Cruz, v. 100, n. 4, p. 397-401, 2005. 
ISHIDA, I.; DE MELLO, J. C.; CORTEZ, D. A. G.; FILHO, B. P.; UEDA-NAKAMURA, T.; NAKAMURA, C. V. Influence of tannins from Stryphnodendron adstringens on growth and virulence factors of Candida albicans. $J$ Antimicrob. Chemother., v. 58, p. 942-949, 2006.

KOSTER, R.; ANDERSON, M.; DE BEER, E. J.Acetic acid for analgesic screening. Fed. Proc., v. 18, p. 412-426, 1959.

LIMA, J. C. S.; MARTINS, D. T. O.; DE SOUZA, P. T. Jr. Experimental evaluation of stem bark of Stryphnodendron adstringens (Mart.) Coville for anti-inflammatory activity. Phytother. Res., v. 12, p. 212-220, 1998.

LOPES, G. C.; SANCHES, A. C. C.; NAKAMURA, C. V.; DIAS FILHO, B. P.; HERNANDES, L.; MELLO, J. C. P. Influence of extracts of Stryphnodendron polyphyllum Mart. and Stryphnodendron obovatum Benth. on the cicatrisation of cutaneous wounds in rats. $J$. Ethnopharmacol., v. 99, p. 265-272, 2005.

NEVES, M. C. L.; JORGE NETO, J.; IFA, D. R.; FRACASSO, J. F.; LEPERA, E. Z. P.; SILVA, R. F. P. Estudo dos efeitos farmacológicos produzidos pelos extratos aquosos de hamamelis e Barbatimão. In: VIII REUNIÃO UNUAL DA FEDERAÇÃO DE SOCIEDADES DE BIOLOGIA EXPERIMENTAL, 8., Caxambu, 1992. Resumos. São Paulo: FeSBE, 1992. p. 7.
PANIZZA, S.; ROCHA, A. B.; GECCHI, R.; SILVA, R. A. P. Stryphnodendron barbadetiman (Vellozo) Martius: teor em tanino na casca e sua propriedade cicatrizante. Rev. Cien. Farm., v. 10, p. 101-106, 1988.

PARKHOUSE, J.; PLEUVRY, B. J.; REES, J. M. H. Analgesic Drugs. Oxford: Blackwell, 1979, p. 1-5.

RAJ, P. P. Pain mechanism. In: RAJ, P. P. (Ed.) Pain Medicine: a comprehensive review. St. Louis: Mosby, 1996, p. 12-23.

SANCHES, A. C. C; LOPES, G. C.; NAKAMURA, C. V.; DIAS FILHO, B. P.; MELLO, J. C. P. Antioxidant and antifungal activities of extracts and condensed tannins from Stryphnodendron obovatum Benth. Rev. Bras. Cien. Farm. v. 41, n. 1, p. 101-107, 2005.

Recebido para publicação em 02 de abril de 2007. Aceito para publicação em 13 de julho de 2007. 